\title{
Общины евангельских христиан-баптистов в Тувинской Народной Республике (1926-1932 гг.)
}

\author{
Николай М. Моллеров \\ Тувинский институт гуманитарных и прикладных социально-экономических исследований, \\ Российская Федерация
}

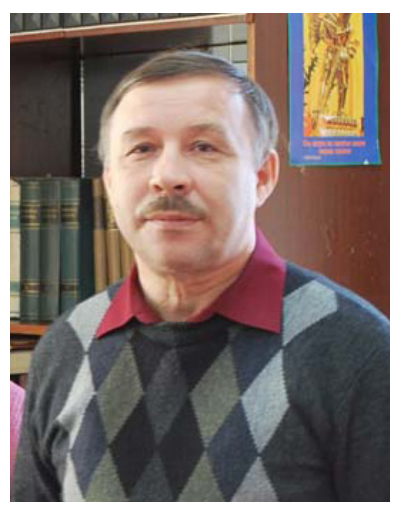

В статье анализируется история распространения баптизма в Туве, которая относится к периоду Тувинской Народной Республики. Актуальность изучения темы обусловлена активизацией современных евангельских христиан-баптистов в России, в том числе в Туве. Более изученных в Туве староверов баптисты в настоящее время превзошли не только активностью, но и численно. За постсоветское время их ряды заметно пополнились тувинцами.

1926-1932 г2. были временем относительной свободы для евангельских христиан-баптистов в Туве. Протестантское движение имело хорошо оформленную и устойчивую структуру в форме двух религиозных общин - Азютской и Успенской. Общины объединяли баптистов и евангельских христиан, которые неплохо сосуществовали друг с другом, с представителями буддийской конфессии и староверами. С православными их отношения были напряженными.

Баптисты играли заметную роль не только в религиозной, но и в политической жизни бывшего Урянхайского края. Демонстрируя хозяйственный успех, они обращали в свою веру даже бывших красных партизан, коммунистов и комсомольцев. Относительным успехом их проповеди пользовались среди тувинского населения.

Влияние баптистов во многом было основано на их серьезном подходе к воспитанию молодежи. Строгое следование религиозным принципам многих поколений баптистов закрепило за ними репутацию людей слова и дела. Молодежи прививали чувство гордости за принадлежность к общине. Среди населения баптисты вели усиленную проповедническую работу, действуя через опорные пункты на местах.

Деятельность евангельских христиан-баптистов в Туве была пресечена в связи с ужесточением антирелигиозной борьбы и коллективизацией в СССР, получившими свое распространение и в советской зарубежной колонии на территории ТНР.

В научный оборот вводятся новые исторические источники, в том числе ранее находившихся под грифом «секретно» (сводки Управления Государственной Внутренней Политической Охраны ТНР и др.).

Ключевые слова: баптист; баптизм; протестантизм; Тувинская Народная Республика; Тува; тувинцы; история Тувы; УГВПО; советская зарубежная колония; Христомол; антирелигиозная комиссия

\section{Для цитирования:}

Моллеров Н. М. Общины евангельских христиан-баптистов в Тувинской Народной Республике (1926-1932 гг.) [Электронный ресурс] // Новые исследования Тувы. 2019, № 1. URL: https://nit.tuva. asia/nit/article/view/827 (дата обращения: дд.мм.гг.). DOI: 10.25178/nit.2019.1.2

Моллеров Николай Михайлович - доктор исторических наук, главный научный сотрудник сектора истории Тувинского института гуманитарных и прикладных социально-экономических исследований. Адрес: 667000, Россия, г. Кызыл, ул. Кочетова, д. 4. Тел.: +7 (394-22) 2-39-36. Эл. адрес: igi@tigpi.ru

Mollerov Nikolai Mikhailovich, Doctor of History, Chief Research Fellowr, Sector of History, Tuvan Institute for the Humanities and Applied Social and Economic Studies. Postal address: 4 Kochetov Str., Kyzyl, 667000 Russia. Tel.: +7 (394-22) 2-39-36. E-mail: igi@tigpi.ru 


\title{
Evangelical Christian (Baptist) communities in the People's Republic of Tuva (1926-1932)
}

\author{
Nikolai M. Mollerov \\ Tuvan Institute for the Humanities and Applied Social and Economic Studies, \\ Russian Federation
}

The article analyzes the history of the spread of Baptism in Tuva during the period of the Tuvan People's Republic. The relevance of the study is due to an increase in the activity of contemporary Evangelical Christians (Baptists) in Russia, including Tuva. In terms of both public activity and numbers, Baptists have surpassed Old Believers, which have traditionally been better studied in Tuva. During the post-Soviet years, the community saw a conversion of quite a number of ethnic Tuvans.

1926-1932 was a time of comparative freedom for Evangelical Christians (Baptists) in Tuva. The protestant movement had a well-designed and sustainable structure, which included two religious communities - Azyutsky and Uspensky, wherein Baptists and other groups of Evangelical Christians coexisted well, also finding common ground with Buddhists and Old Believers. However, their relations with Orthodox communities were rather strained.

Baptists played a significant role not only in religious but also in the political life of the former Uriankhai krai. By displaying their economic success, they manage to convert even former Red partisans, Communists and Komsomol members. Their preaching had a comparative success among the Tuvan population.

The influence Baptists had was largely based on their serious approach to the education of young people. Strict adherence to the religious principles of many generations of Baptists consolidated their reputation as people of word and deed. Young people were instilled with a sense of pride in belonging to the community. Among the population, the Baptists conducted intensive preaching, acting via local "strongholds".

Baptists' activity in Tuva was suppressed due to enhanced anti-religious struggle and collectivization in the USSR, which spilled over into the Soviet community on the territory of the PRT.

New historical sources, including those previously classified (reports of the Department of State Internal Political Security of the PRT, etc.), are now being introduced into scientific circulation.

Keywords: Baptist; Baptism; Protestantism; People's Republic of Tuva; Tuva; Tuvans; Tuvan history; Department of State Internal Political Security; Soviet foreign colony; Christomol; anti-religious committee

\section{For citation:}

Mollerov N. M. Evangelical Christian (Baptist) communities in the People’s Republic of Tuva (1926-1932). The New Research of Tuva, 2019, no. 1 [on-line] Available at: https://nit.tuva.asia/nit/article/view/827 (accessed:... ). DOI: 10.25178/nit.2019.1.2

\section{Введение}

Историки и религиоведы считают, что дать объективную историю евангельских христианбаптистов очень трудно. В сохранившихся документальных источниках она отражена неполно, описание событий в них нередко излагается пристрастно. Данное суждение вполне справедливо в отношении истории религиозной деятельности евангельских христиан-баптистов в России и ее регионах. Вместе с тем, эта тема для Тувы актуальна, поскольку деятельность баптистских организаций в ней в последние два десятилетия заметно активизировалась. Это побуждает обратиться к истокам баптистского движения в регионе, ко времени, когда уже закладывались предпосылки для их роста в наши дни. Сведения, приведенные в настоящей научной статье, могут представлять интерес для размышлений в данном дискурсе.

Большое значение для изучения проблемы имеет введение в научный оборот новых исторических источников, в том числе ранее находившихся под грифом «секретно». К таким источникам, в частности, относятся сводки службы безопасности Тувинской Народной Республики (ТНР) - Управления Государственной Внутренней Политической Охраны (УГВПО, создано в 1925 г.), хранящиеся в Российском государственном архиве социально-политической истории (РАСПИ) и использованные в настоящей работе. 
Несмотря на контроль УГВПО ТНР, это было время относительной свободы для евангельских христиан-баптистов в Туве. Их деятельность год от года расширялась и набирала обороты. Баптизм был наиболее развит в Турано-Уюкском и Подхребтинском районах советской зарубежной колонии в ТНР. Можно отметить, что в условиях НЭПа баптисты адаптировались в Туве неплохо. Большинство из них жили зажиточно. В источниках отмечалось, что, демонстрируя хозяйственный успех, они обращали в свою веру даже бывших красных партизан, коммунистов и комсомольцев. Относительным успехом их проповеди пользовались среди тувинского населения.

Сами себя баптисты считали исключительно толерантными, хотя православные христиане были, напротив, убеждены, что они глубоко враждебны другим конфессиям, особенно православной. Каждая община самостоятельно поддерживала связь с Центральным и Сибирским союзами и Минусинской общиной в СССР, а также с русскими единоверцами, проживающими в Америке (США, Калифорния). Коллективизация, изменение государственной религиозной политики, усиление антирелигиозной работы в СССР привели к свертыванию деятельности евангельских христиан-баптистов в Туве.

Для исторического тувиноведения данная тема актуальна и интересна по ряду причин. Во-первых, деятельность евангельских христиан-баптистов в Туве еще почти не изучалась: в советский период тема считалась неактуальной, а за последние два с лишним десятилетия увидела свет всего одна научная работа с кратким и фрагментарным отображением периода 1917 - первой половины 1920-х гг. (Бадмаев и др., 2006). Вторая половина двадцатых годов $\mathrm{XX}$ в. в ней правомерно охарактеризована как период относительно свободной религиозной жизни, в том числе активной миссионерской деятельности среди тувинцев. И этим, в общемто верным суждением, все и ограничивается. Внимание религиоведов в наши дни больше привлекает деятельность современных протестантских общин в Туве.

Во-вторых, следует учесть, что баптисты сыграли заметную роль не только в религиозной, но и в политической жизни бывшего Урянхайского края. За годы нахождения в Туве монгольского отряда члены комиссии-баптисты провели три съезда представителей русского населения.

В-третьих, умаление роли баптистов, именование их сектантами, похоже, уходят в небытие, такая позиция выглядит все менее и менее убедительной. Сегодня все чаще звучат слова признания их мировой конфессией. В том числе и в связи с тем, что численность членов баптистской церкви такова, что называть ее сектой неправильно. В настоящее время евангельские христиане-баптисты - это самая многочисленная протестантская деноминация в России и вторая по величине христианская конфессия в стране, ее церкви и общины имеются в городах и многих поселках России. Так, более изученных в Туве староверов евангельские христиане-баптисты в настоящее время превзошли не только активностью, но и численно. За постсоветское время их ряды заметно пополнились тувинцами.

Учитывая все выше сказанное, можно считать заявленную в настоящей работе тему актуальной и научно значимой. Тем более, что она посвящена пока совершенно неизученному периоду в религиозной жизни христиан-баптистов в Туве и в основном опирается на новые, ранее никем не изученные источники, к которым относятся, прежде всего, сводки УГВПО ТНР (РГАСПИ) в фонде 495 (Коминтерна). Далее по степени значимости идут протоколы заседаний райбюро ВКП (б) в Туве из фонда 32 (райбюро РКП (б)) Центра архивной документации партий и общественных организаций Государственного архива Республики Тыва (ЦАДПОО ГАРТ), сведения из печатного органа райбюро ВКП (б) и Исполкома Русской самоуправляющейся трудовой колонии (РСТК) - газеты «Красный пахарь». И, наконец, следует назвать сделанные нами в 1980-1990-е годы записи бесед с информантами-бывшими баптистами, которые, к сожалению, ушли из жизни (А. З. Колодкиным и С. Г. Терских). Воспоминания Авдея Захаровича Колодкина хранятся в Научном архиве Тувинского института гуманитарных и прикладных социально-экономических исследований (НА ТИГПИ). На них в статье не делались ссылки, но они помогли автору на начальном этапе наметить круг вопросов по изучению проблемы. 
Краткие записи бесед с Степаном Григорьевичем Терских находятся в личном архиве автора. Кроме того, в ходе поисковой работы в фондах Красноярского краевого музея (ККМ) удалось обнаружить материалы чиновника Переселенческого управления в Туве А. П. Ермолаева с наиболее ранним (1916) упоминанием о баптистах в Туве (Ф. 7886/211).

\section{Проникновение баптистов в Туву}

Баптизм вышел на историческую арену в начале XVII в. как одно из направлений протестантизма в Англии (Религиоведение, 2002: 332-333; Сперанская, Леоненкова, Электр. ресурс; Крыжановский, 2011). В 1867 г. баптистская церковь возникла в России. К концу XIX в. вероучение баптизма распространилось по всей Российской империи. В начале последнего десятилетия XIX в. первые переселенцы-баптисты появились в Сибири. Начиная с 1905 г. почти ежегодно, а иногда и дважды в год проходили съезды Сибирского братства. На съезде 1907 г. в г. Омске был образован Сибирский отдел Всероссийского Союза баптистов.

В 1910-1916 гг. российское государство в очередной раз поставило протестантов в бесправное положение. Возможно, именно их преследованиями объясняется переселение из России в Туву организованной группы баптистов, образовавших здесь в 1910 г. пос. Березовку (1910). По данным чиновника Переселенческого управления в Туве А. П. Ермолаева за 1916 г., почти 60\% российских переселенцев в Туве были православными (русские, белорусы, украинцы), $23 \%$ - старообрядцами (главным образом русские), менее $4 \%$ исповедовали ислам (татары и башкиры), почти 9\% относились к католикам, протестантам и баптистам (немцы, поляки, латыши). Вероисповедание $4 \%$ установить не удалось, какая-то часть из них могла быть атеистами. Почему-то баптистов и лютеран Ермолаев к протестантам не относил, разделив их на самостоятельные религиозные группы (Красноярский краевой музей - ККМ. Ф. 7886/211. Л. 87; История Тувы, 2007: 61).

1917-1920 гг., несмотря на революционные события и Гражданскую войну в стране, считаются в истории годами пробуждения баптизма по всей Сибири. Тогда во многих городах и селах Сибири возникли новые общины и группы. Не стал исключением и протекторат Российской империи - Урянхайский край, в котором проживало более 10 тыс. переселенцев из центральных и сибирских губерний государства.

В 1917 г. по окончании срока ссылки в Туву прибыл убежденный проповедник баптизма, бывший пресвитер Минусинского района Николай Александрович Зелинский. Сначала он создал баптистскую общину в пос. Уюк, куда потянулись верующие и сочувствующие из других русских поселков. В научной литературе утверждается, что Н. А. Зелинский образовал первую общину евангельских христиан-баптистов в Туве. «Этот духовный лидер тувинских баптистов, говорится в упомянутой выше монографии, - в начале $1890-\mathbf{x}$ гг. был осужден за приверженность евангельской вере, лишен графского титула и состояния и выслан в Сибирь» (Бадмаев и др., 2006: 32).

О начале пробуждения Тувы к баптистской вере сложилась легенда. Согласно ей, азютские ${ }^{1}$ староверы-охотники как-то приобрели Библию. Они стали читать книгу Исайи и открыли для себя истину, что иконам поклоняться не следует, а пост должно совершать иначе, чем они себе до той поры представляли. Обнаруженные ими расхождения книжного знания с обрядовой практикой побудили их обратиться за разъяснениями к «немолякам». Так в то время называли баптистов Зелинских за то, что они не молились иконам. Приехав в Уюк, староверы попали на богослужебное собрание местных баптистов. После собрания «немоляки» с ними побеседовали. Удовлетворенные полученными ответами на свои вопросы, азютские староверы «уверовали» и по возвращении домой поделились новыми религиозными знаниями с односельчанами. Такова баптистская легенда духовного пробуждения в Туве.

\footnotetext{
${ }^{1}$ Азютские - от названия поселка Азют.
} 
Представляется, что это лишь привлекательная версия действительных, вполне обычных для религиозной практики событий. Ведь до пробуждения Азюта, были еще баптистские общины в Березовке и Уюке. Н. А. Зелинский же вскоре перебрался в Березовку, где также возглавил местную общину. Прожили Зелинские в Туве до 1924 г., а затем по примеру другой баптистской семьи и родственников Лесковских перебрались в Северную Америку. Лесковских же побудили покинуть Туву революционные события, во время которых один из представителей этой фамилии, встав на сторону революционно настроенных колонистов в Туве, был ранен в перестрелке с казаками.

Следует отметить, что проживавшие в Туве баптисты с тех пор постоянно поддерживали связь со своими единоверцами в Калифорнии, которая не прерывалась в период ТНР и в советское время. Один из моих информантов, выходец из известной баптистской семьи Степан Григорьевич Терских еще в годы перестройки переписывался с потомками эмигрантов из Тувы в г. Сан-Франциско (Калифорния). Он показывал мне полученные оттуда фотографии и открытки, включал магнитные записи с религиозными песнопениями под гитару.

Следует отметить, что во время военных событий 1917-1921 гг. в регионах Сибири погибло много опытных руководителей баптистов. Их община в Туве также понесла потери. В период военной интервенции в Туве в 1919-1920-е гг. они, как никто из русских переселенцев, подошли на роль переговорщиков с командованием монгольского военного отряда и возглавляли Комиссию по делам с Монголией. Присущий баптистам отказ от применения оружия по религиозным мотивам расположил к ним державшуюся на военном превосходстве оккупационную власть. Хотя члены комиссии и действовали в рамках дозволенного интервентами, их усилиями отношения военного отряда с российскими переселенцами стали менее драматичными, чем в начальный период оккупации. Но в 1919 г. был расстрелян красноармейцами первый председатель Комиссии по делам с Монголией Алексей Иванович Алексеев. В 1920 г. пресвитер общины Н. А. Зелинский с сыном Павлом был арестован по подозрению в нелегальной политической деятельности, но затем отпущен. По причине ослабления руководства общины начали слабеть идейно и организационно. В европейской части России и Сибири в годы Гражданской войны отмечается заметный спад баптистского движения.

В Туве на фоне продолжавшегося переселения русских крестьян, среди которых были и баптисты, спад почти не ощущался. В 1918 г. староверы с Алтая недалеко от Березовки основали Успенку. В 1921 г. в Успенке поселилась группа выходцев из с. Усинского, которая образовала вторую общину евангельских христиан - баптистов. Ее духовными лидерами стали 3. Д. Колодкин и братья Демьян и Викул Медведевы. Затем две практически единоверных общины Березовская и Успенская - объединились в одну с центром в Успенке (Бадмаев и др., 2006: 32).

Когда я расспрашивал С. Г. Терских об истории основания пос. Успенка - одного из центров баптизма в Туве в прошлом, он замыкался и почти ничего не рассказывал. Название поселка «Успенка» он, явно лукавя, связывал не с успением Божьей матери (день памяти у православных, связанный с завершением ею жизненного пути), а с расторопностью колонистов, которые, якобы, «успели» занять место под поселок. Такое уклончивое поведение объяснялось тем, что баптисты не чтят Богородицу, являвшуюся для православных народной заступницей. Вообще же, его нежелание говорить о жизни в Успенке могло быть связано и с преследованиями баптистов в 1930-е гг. (см. об этом ниже). Теперь, когда стали известны трагические страницы раскулачивания поселка, затронувшего и семью Терских, такое поведение информанта становится вполне понятным.

Сначала богослужения проводили поочередно в домах верующих. В 1924 г. в поселке был построен дом молитвы. Члены Успенской общины отличались активностью в проповеднической деятельности. На общем фоне особо «выделялась семья Алексеевых, отличавшаяся образованностью, знанием религиозных текстов и обрядности» (там же: 33). Алексеевы привезли в Туву печатный станок, на котором был, в частности, напечатан достаточным тиражом Новый Завет. Вскоре почти в каждой баптистской семье имелась эта святая книга. После трагической гибели отца семейства Алексеевы вынуждены были уехать из Тувы к родственникам. 
В 1925 г. на строительство в г. Кызыл приехали рабочие из разных городов Сибири, среди которых оказались и евангельские христиане-баптисты.

В СССР 23 октября 1922 г. состоялось первое совещание организованной при ЦК РКП (б) антирелигиозной комиссии во главе с Емельяном Ярославским (Губельманом). Секретарем комиссии стал начальник 6-го отделения секретного отдела Объединенного государственного политического управления (ОГПУ) Евгений Тучков. В протоколе заседания комиссии от 26 июня 1923 г. есть запись: «Поручить ГПУ усилить работу по разложению сектантства» (РГАСПИ, Ф. 17. Оп. 112.Д. 565а. ЛЛ. 12-13). В Туве же в первой половине 1920-х гг. райбюро РКП (б) и власть, как правило, шли навстречу верующим. Так, на заседании райбюро РКП (б) 19 февраля 1922 г. рассматривалась просьба баптистов об освобождении их от трудовой повинности по воскресеньям и религиозным праздникам, а также от воинской повинности. Постановили: «разрешить в зависимости от ...обстановки» (ЦАДПОО ГАРТ. Ф. 32. Оп.1. Д. 18. Л. 6) и проконсультироваться по данному вопросу в Сибревкоме.

\section{Численность и степень активности баптистов в середине 1920-х годов}

Предметом исследования в данной статье является почти не изученная религиозная деятельность баптистов в Туве во второй половине 1920-х гг.

Несмотря на контроль УГВПО ТНР, это было время относительной свободы для евангельских христиан-баптистов в Туве. В акте обследования советской зарубежной колонии в Туве комиссией Сиббюро ВКП(б), работавшей летом 1926 г. отмечено, что среди верующих 17\% советских колонистов являлись баптистами, $32 \%$ - староверами и остальные - православными (Центр архивной документации политических организаций и объединений Государственного архива Республики Тыва - ЦАДПОО ГАРТ. Ф. 32. Оп. 1. Д. 75. Л. 12).

Между тем, в докладе райбюро ВКП (б) в Туве за 1926 г. (ЦАДПОО ГАРТ. Ф. 32. Оп. 1. Д. 90. ЛЛ. 32-33) говорится о доминировании баптизма среди других религиозных течений. Зная статистику, можно предположить, что речь в нем шла не о численном доминировании, а скорее о высокой активности баптистов в распространении своего вероучения, как среди русских, так и тувинцев. При этом баптизм был наиболее развит в Турано-Уюкском и Подхребтинском районах советской колонии в Туве. В первом из них центр баптистской общины к тому времени из пос. Уюк переместился в пос. Азют (60 верующих и сочувствующих). Во втором названном районе в пос. Успенка проживали 53 баптиста, в Кызларике -70.

Можно отметить, что в условиях нэпа баптисты адаптировались в Туве неплохо. Две трети из них жили зажиточно. В докладе отмечалось, что сфера деятельности баптистов неуклонно расширялась, и, демонстрируя хозяйственный успех, они обращали в свою веру даже бывших красных партизан. По мнению членов райбюро ВКП (б), увлечение баптизмом происходило главным образом из-за низкой культуры колонистов и отсутствия антирелигиозной работы в советской зарубежной колонии в Туве. Отсюда видно, что привлекательность и потенциал самого учения недооценивались.

\section{Отношение баптистов к подрастающему поколению}

Советские и партийные работники обвиняли христиан-баптистов в том, что они не допускали к образованию своих детей. На самом деле, с первых лет существования баптизма в России вопрос образования не сходил с повестки дня баптистских съездов всех уровней. Но баптистов принципиально не устраивали светские школы, где воспитывали атеистов. Они практиковали библейское образование, согласно которому всякий возрожденный христианин является учеником Иисуса Христа и всю жизнь учится в школе, где Учитель - Дух Святой, а учебник - Библия (для евангельских христиан - Евангелие). Для своих детей они открывали начальные школы. 
С целью религиозного воспитания молодежи в пос. Азют предпринималась попытка создания местной организации Союза христианской молодежи (Христомол, существовал в России с начала ХХ в.) (ЦАДПОО ГАРТ. Ф. 32. Оп. 1. Д. 90. Л. 34). Эта организация, в отличие от комсомола советской колонии или ревсомола ТНР, имела сложившиеся традиции и немалый опыт работы среди молодежи. Вопрос о ее создании вынесли на предстоящий в 1921 г. Всеколонистский съезд баптистов. Но удалось ли создать Христомол в Азюте, сказать определенно трудно. Можно лишь отметить, что в доступных источниках за 1920-е гг. эта организация, как действующая, нигде не упоминается.

Вместе с тем, на работу среди молодежи баптисты обращали самое серьезное внимание. Следует отметить, что российские баптисты к тому времени накопили большой опыт работы с молодежью. Неудивительно, что им удавалось обращать в свою веру даже комсомольцев. Так, в пос. Тарлаг после двух посещений баптистами комсомолец Петр Сенокосов, увлекшись вопросами веры, охладел к комсомольской работе, реже стал ходить на комсомольские собрания (РГАСПИ. Ф. 495. Оп. 1. Д. 25. Л.19). Молодые члены Успенской общины посещали окрестные села Арголик, Балгазын, Огневка, проповедовали там Евангелие и исполняли духовные песнопения. В этих селах у них появились единомышленники, которые стали посещать религиозные собрания в Успенке (Бадмаев и др., 2006: 33).

Острым для христиан-баптистов в Туве являлся вопрос о воинской службе молодежи. С 1926 г. после упразднения части особого назначения (ЧОН) советской колонии велся ежегодный призыв в ряды Красной Армии в СССР. Многие молодые советские граждане из Тувы проходили военную службу в 26 Златоустовской дивизии 5 армии Рабоче-Крестьянской Красной Армии, дислоцированной в г. Красноярске. Ранее, когда призыва в армию из советской зарубежной колонии в Туве еще не было, евангельские христиане баптисты в соответствии с решением своего IX съезда от 1923 г., рассматривали служение в армии в качестве обязательного оброка (Большая Советская Энциклопедия, 1931: 810). Но затем были внесены изменения в советское законодательство согласно новому закону Президиума ЦИК СССР об обязательной военной службе от 18 сентября 1925 г. суд мог освободить верующих от воинской обязанности. Основанием для положительного решения этого вопроса являлась их принадлежность по рождению и воспитанию к семьям, религиозные учения которых запрещают отбывание военной службы с оружием в руках.

Строгое следование религиозным принципам многих поколений баптистов закрепило за ними репутацию людей слова и дела. Молодежи прививали гордость за принадлежность к общине. В связи с этим Макс Вебер, основываясь на своих наблюдениях в Америке, писал: «Принадлежность к секте (в данном случае автор пользуется широко распространенным термином. - H. M.) - в противоположность к церкви, которая «дана» человеку от «рождения», является своего рода нравственным (прежде всего в деловом отношении) аттестатом личности» (Вебер, 1990: 227).

\section{Отношение с партийными органами и властями}

Антирелигиозная работа среди русского населения в Туве, где государственное строительство осуществлялось почти с нуля, началась с отставанием от СССР на 3-4 года. В ТНР Служба государственной безопасности, в форме Управления государственной внутриполитической государственной охраны (УГВПО), была создана в 1925 г., антирелигиозную комиссию при райбюро ВКП (б) в советской колонии организовали в начале 1927 г.

На заседании райбюро ВКП (б) от 2 февраля 1927 г. секретарь партийной организации Авдеев выступил с докладом о сектантском движении в колонии. В принятом по нему постановлении отмечалось: «сектантское движение, особенно баптисты, в последнее время активизировалось...» (ЦАДПОО ГАРТ. Ф. 32. Оп. 1. Д. 82. Л. 18). Райбюро наметило провести широкую ударную антирелигиозную работу, в первую очередь, против баптистов. Руководство этой работой поручалось антирелигиозной комиссии из 7 человек, которая собиралась после двухме- 
сячной теоретической подготовки отправиться по районам РСТК для атеистической агитации и организации ячеек безбожников (ЦАДПОО ГАРТ. Ф. 32. Оп. 1. Д. 90. Л. 35). Кроме секретаря райбюро, в помощь комиссии были выделены представитель Коминтерна в Туве С. А. Нацов, советский консул А. Г. Старков, председатель исполкома РСТК Г. В. Фотеев и торговый агент СССР в Туве А. А. Васильев. Комиссии поручалась разработка плана антирелигиозной работы. Предполагалось обратиться в СССР для получения руководящих материалов.

В государственных информационных сводках УГВПО, ежемесячно предоставляемых Совету Министров ТНР, содержался раздел «По религиозным культам» с подразделом «Баптисты».

Руководящий состав Успенской общины при любом удобном случаев критически высказывался о мероприятиях власти. Так, Зайцев и Терских часто указывали на тяжесть налогов, сопровождая свои слова выдержками из Евангелие и обвиняя при этом русских сотрудников, работающих в Тувинском правительстве. Демьян Медведев сетовал: «Какая же это свобода, когда существует назначенчество» (РГАСПИ. Ф. 495. ОП. 153. Д. 25. Л. 22). Ярким примером назначенчества он считал выборы председателя Исполкома РСТК. По его словам, мужики и голосовали только потому, что им «велят голосовать» (там же). Высказывал недовольство тем, что «учреждения не обращают должного внимания на просьбы мужика», «на съездах мужику говорить не дают, притесняют, чуть голос подал, сейчас же тебя на заметку» (там же: л. 23).

Благовестник Успенской общины Зайцев говорил: «Баптизм сейчас борется со всеми религиозными культами, которые со временем уступят дорогу баптистскому учению, останутся две партии: баптизм и коммунизм, и первый должен быть победителем» (там же). Община также начала присматриваться к бывшим коммунистам, выбывшим по разным причинам из рядов ВКП (б). Так, объектом внимания для них стал проживавший в Верхне-Никольском бывший коммунист Щуревский, исключенный из партии за халатность, проявленную на посту председателя райсовета, и осужденный к трем месяцам принудительных работ.

Член Азютской общины Коптев в разговоре на тему об отношениях Компартии и баптизма сказал: «Коммунистическая партия с их идейным течением тождественна, но разница в том, что компартия проповедует атеизм, а они с этим борются и будут бороться» (там же: л. 61).

6 марта 1927 г. на улицах Кызыла были разбросаны листовки размером 7 на 11 см., с отпечатанной на обеих сторонах фразой: «Неужели думаешь ты, человек, что избежишь суда Божия». Текст был отпечатан в ручной домашней типографии. По предварительным данным УГВПО, их разбросал Харлампий Пешкин (там же: л. 23).

\section{Центры, направления и формы религиозной деятельности}

Изучая религиозную деятельность евангельских христиан-баптистов в Туве, УГВПО определило, что основной ее тенденцией в марте 1927 г. являлось усиление проповеднической работы (благовестия) среди населения, а главной тактической задачей - подыскание опорных пунктов в местах компактного проживания людей для дальнейшего развертывания своей работы (РГАСПИ. Ф. 495. ОП. 153. Д. 25. ЛЛ. 17-18).

Отмечалось, что за последнее время в двух имеющихся в колонии общинах - Азютской и Успенской - проповедническая работа среди населения усилилась. Чаще, чем в 1926 г., стали осуществляться выезды «в народ» пресвитеров и благовестников общин. Толчок всей этой работе дал прошедший 19 января 1927 г. годовой отчетный съезд представителей местных баптистских общин, на котором был сделан вывод, что, несмотря на численный рост общин и отдельные успехи, работа по вовлечению в общины новых членов проводилась недостаточно активно (РГАСПИ. Ф. 495. ОП. 1. Д. 25. Л. 18). Действуя энергично, общины стали включать в сферу своей деятельности новые поселки и в некоторых из них за короткий срок сумели добиться заметных успехов. Члены Азютской общины в течение февраля-марта 1927 г. дважды посетили пос. Тарлаг (второй раз с хором), где им удалось пробудить интерес к своему вероучению у Якова Дмитриева и Петра Сенокосова. Свою дальнейшую работу в поселке они 
надеялись проводить через них. В планах общины значился район Тоджи, где в пос. Севи проживал «подающий надежды» Христофор Чащин (там же).

Члены Успенской общины «обслуживали» поселки Краснояровка и Кызларик (правильно: Кызыл-Арыг), а также намеревались перенести свою деятельность в Максимовку, Владимировку и Верхне-Никольское. Отмечено, что староверческим поселком они уделяли особое внимание, видимо, находя там больше сочувствия и понимания.

Согласно приведенной в сводке УГВПО таблице (РГАСПИ. Ф. 495. ОП. 153. Д. 25. Л. 61), по состоянию на 1 мая 1927 г. район действия баптистских общин в ТНР выглядел следующим образом:

\begin{tabular}{|l|l|c|l|}
\hline & Наименование общин & Кол-во членов, чел. & \multicolumn{1}{|c|}{$\begin{array}{l}\text { Наименование поселков, } \\
\text { обслуживаемых общзинами }\end{array}$} \\
\hline 1 & Азютская община & 59 & $\begin{array}{l}\text { a) Ленинка } \\
\text { б) Тарлаг } \\
\text { в) Заимка Азарова }\end{array}$ \\
\hline 2 & Успенская община & 77 & $\begin{array}{l}\text { a) Березовка } \\
\text { б) Краснояровка } \\
\text { в) Кызыл-Арыг } \\
\text { г) Кызыл }\end{array}$ \\
\hline
\end{tabular}

Работа в новых, еще не вовлеченных в работу поселках обычно начиналась с чтений религиозных текстов, с их толкования, согласно вероучения. Потом переходили к насущным жизненным вопросам: налогам, отношению к власти, при этом резюмировали, что все происходящее - от бога, что это наказание за грехи, которое надо терпеть. Если же «подающий надежды» нуждался материально, то ему помогали, чтобы вызвать к себе расположение. Были зафиксированы случаи, когда, получив помощь, сочувствующие вступали в общину.

Силами обеих общин собирались построить в г. Кызыле заезжий братский дом или устроить братское подворье. Это позволило бы благовестникам вести активную работу среди горожан всех национальностей. Однако из-за недостатка времени и средств выполнение задуманного откладывалось. Но в качестве заезжего использовался дом Михайлицина по улице Ленинской № 58. Здесь с 20 февраля 1927 г. группой из шести человек уже проводились обрядовые собрания.

В группу входили: принявший в январе 1927 г. баптистское крещение Харлампий Нестерович Пешкин, бывший комсомолец, грамотный, по профессии кожевник; ранее проживавший в Успенке и член ее общины Афанасий Семенович Буйновский, который устроился на кожевенный завод Нестора Пешкина (попутно отметим, что до Нестора Пешкина в исторических источниках о Туве не был назван ни один нэпман, владелец частного предприятия, это первый зафиксированный нами факт), грамотный, имевший задание общины организовать в городе группу верующих; жена Афанасия Евдокия Буйновская, бывшая учительница в пос. Успенка, где она весной 1926 г. вышла замуж и приняла крещение. Буйновские, проживая в Успенке, организовали там церковный хор и руководили им, они также преподавали успенским детям нотную грамоту (Бадмаев и др., 2006: 33). В группу также входил владелец кожзавода, отец Харлампия Пешкина Нестор, сочувствующий и еще не крещеный. Последними двумя членами группы были супруги Михайлицыны, кызылчане, грамотные, не крещеные. По субботам и воскресеньям группа собиралась в столярной мастерской у Михайлицына. (РГАСПИ. Ф. 495. Оп. 153. Д. 25. Л. 20).

На обрядовых собраниях иногда присутствовало до 20 человек. За исключением шести кызылчан, это были приезжие из поселков. К работе среди населения города пока не приступали. Обрядовые собрания проводились в общинах повсеместно. Успенская община, кроме таких собраний по субботам и воскресеньям, проводила по средам членские собрания и по четвергам - специальные женские, призванные углубить работу среди женщин, состоящих в общине, чтобы затем через них повести работу с женщинами, которые в общину не входили. 


\section{Религиозная работа среди тувинцев}

Христиане-баптисты считали, что Бог и сотворенный им мир не имеют национальной принадлежности, что Иисус Христос умер на кресте Голгофы за грехи всех людей, вне зависимости от расы, цвета кожи или географического положения.

В Азютской общине в январе-феврале 1927 г. велась активная работа среди тувинского населения. Баптисты, пользуясь своим влиянием на аратов, побудили их обеспечить дровами хурээ близ Азюта.

Затем произошел неприятный инцидент. Когда проживающий в работниках у Терентия Охотникова тувинец окончательно перешел в общину, то его родственники новообращенного проявили недовольство. Они заявили на Охотникова в Министерство юстиции ТНР. В результате тому пригрозили штрафом, а новообращенному баптисту-тувинцу приказали подчиниться родственникам. Из-за этой истории Азютская община работу среди тувинцев своего района временно свернула.

В то же самое время в Успенской общине работа среди тувинцев усилилась. В период с января по март 1927 г. ее члены совершили две поездки к ламам Мочегенского хурэ и провели с ними беседы, буддисты этого хурэ также дважды посетили общину. После этих визитов и бесед тувинцы - двое мужчин и женщина - изъявили желание принять крещение побаптистски. В работе среди тувинцев стали добиваться не просто обращения их в свою веру, но и качественного подбора новообращенных.

Широтой взгляда на проблему обращения тувинцев в баптизм отличался пресвитер Успенской общины Василий Коптев. В одной из своих бесед с верующими он сказал: «В будущем русские и тувинцы сольются в одну Общину» (РГАСПИ. Ф. 495. Оп. 153. Д. 25. Л. 21). В процессе миссионерской деятельности в Азютскую общину были завербованы несколько тувинцев. Не скрывалось намерение членов общины распространить религиозную деятельность на всю Туву. Успенская община получила от Федеративного Союза Баптистов СССР от 16 февраля 1927 г. за № 775 отношение, в котором Союз выражал радость в связи с успешной работой общины «среди туземного населения». (РГАСПИ. Ф. 495. ОП. 153. Д. 25. Л. 61). В нем также сообщалось о желании получать информации о работе общины и в дальнейшем. В УГВПО ТНР, напротив, полагали, что отношение тувинцев к баптистам было отрицательным.

Сами себя баптисты считали исключительно толерантными, хотя православные христиане были, напротив, убеждены, что они глубоко враждебны другим конфессиям, особенно православной.

В апреле 1927 г. к обозначенным выше тактическим задачам общин добавилась еще одна развертывание работы и подыскание опорных пунктов среди тувинского населения. Добавились такие общие задачи как «закрепление своего положения среди населения и веры в Бога среди членов общин» (РГАСПИ. Ф. 495. ОП. 153. Д. 25. Л. 60). Их постановка и выполнение связывались с выездом антирелигиозной комиссии райбюро ВКП (б) для ведения атеистической пропаганды в районы. Начало практической работы комиссии они расценили как «начало гонения за веру Христа».

С началом антирелигиозной работы райбюро ВКП (б) в Туве усиление своей деятельности среди населения обе баптистские общины стали рассматривать как одну из актуальных задач, и все свои лучшие силы направляли для проповеднической работы среди населения.

\section{Руководящие органы и внешние связи баптистских общин}

Помимо открытых собраний в обеих общинах (в Успенской чаще) устраивались закрытые собрания, на которых присутствовали только действительные члены общины. На закрытых собраниях обычно проводились выборы делегатов на съезды, членов Совета общины и благовестников, обсуждались вопросы о работе среди населения, зачитывались руководящие письма и информации Центрального и Сибирского Союзов и письма от других общин в СССР. 
Каждой общиной устраивались ежемесячные сборы и пожертвования. 40-50\% собранных денежных средств отсылались в Центральный Союз и остальные расходовались на выписку литературы и прочие нужды общин. Каждая община самостоятельно поддерживала связь с Центральным и Сибирским союзами и Минусинской общиной в СССР. Поддерживалась, как мы уже подчеркивали, связь с русскими баптистами, проживающими в Америке. Так, в первых числах марта 1927 г. в Успенскую общину пришло письмо от гр-на Лахина, проживающего в г. Сан-Франциско. В нем Лахин сокрушался по поводу краха своих иллюзий, связанных с Америкой и американцами. Он писал, что ему раньше неверно говорили об Америке, как о царстве Божием и царстве Небесном, и констатировал: «Здесь царство американского доллара» (РГАСПИ. Ф. 495. Оп. 153. Д. 25. Л. 22). О взаимоотношениях с баптистами-американцами он сообщал: «Правда, американцев много, Общины большие, но американцы - не русские. Совсем с другими понятиями и с другими законами, вот почему и не сходятся с русскими» (там же). В апреле 1927 г. член Азютской общины И. Андреев получил из Америки от гр-на Кокорева 48 р. 50 к. УГВПО имело сведения, что денежные переводы из Америки направлялись еще некоторым членам общины (там же: л. 61). Однако эти средства были невелики.

Общины испытывали потребность иметь специалиста-богослова с глубокой теоретической подготовкой. Такого человека они надеялись получить в лице проживающего в Америке Кокорева, который через год по окончании богословского института мог приехать в ТНР. Однако уже через полтора года обстановка в Туве для верующих всех конфессий серьезно обострилась, и вопрос о приезде Кокорева в Туву стал неосуществимым.

\section{Заключение}

В 1929-1941 гг. после постановления СНК СССР от 8 апреля 1929 г. «О религиозных культах» в Советском Союзе и подконтрольной ему советской зарубежной колонии в Туве стал жестко проводиться курс на религиозные гонения. Религия была объявлена опиумом для народа и подлежала искоренению. В тридцатые годы баптистов нередко причисляли к врагам народа. Было арестовано подавляющее большинство церковнослужителей-баптистов и многие активные верующие. Закрытые суды-«тройки» (нелегитимные суды) приговаривали их к лагерным срокам до 25 лет за «антисоветскую агитацию». Так автор энциклопедической статьи «Евангельские христиане» Н. Никольский писал: «По отношению к советской власти евангельские христиане стремились показать себя лояльными. ...По существу, секта является замаскированной контрреволюционной кулацкой организацией, получающей финансовую поддержку из-за границы; истинное ее лицо выявилось в особенности в ее активной борьбе против коллективизации в деревне» (Большая Советская энциклопедия, 1931: 810).

В условиях нэпа правления обоих союзов (евангельских христиан и баптистов) поддерживали предпринимательскую деятельность. В Туве их адепты охотно вступали в простейшие сельхозкооперативы типа машинных товариществ. В 1925 г. машинное товарищество создали баптисты пос. Успенка. Но они же сопротивлялись созданию товарищества по совместной обработке земли (ТО3) в 1928 г., где нормы обобществления хозяйств были выше, чем в машинных товариществах. Так, газета «Красный пахарь» от 14 марта 1930 г. в числе «вредителей», препятствующих коллективизации, называла баптистов Григория, Павла и Петра Терских. Все их единоверцы также отказались вступать в колхоз. На них было заведено «Успенское дело». В результате новых гонений больше всех пострадал пресвитер В. И. Коптев, которого вместе с «раскулаченными» выслали в г. Минусинск. Чтобы оградить свою семью от преследований, он отказался от веры, но это не избавило его самого от гонений. К концу 1930-х гг. в Успенке почти не осталось верующих. Дом молитвы в поселке разобрали. Община перестала существовать.

Азютская община евангельских христиан оказалась в самом центре восстания советских колонистов в Туве весной 1930 г. Здесь обострение было также связано с коллективизацией, с ее перегибами. О судьбах азютских баптистов того времени пока ничего не известно. 
Можно лишь предположить, что и Азютская община в это время была, по меньшей мере, сильно ослаблена.

Лишь в разгар Великой Отечественной войны власть изменила свое отношение к религии и верующим. Тогда же состоялось окончательное объединение Союза баптистов и Союза евангельских христиан в единый Союз евангельских христиан-баптистов (1944 г.).

Таким образом, протестантское движение в Туве, будучи малочисленным, имело хорошо оформленную и устойчивую структуру в форме двух религиозных общин - Азютской и Успенской. Общины объединяли баптистов и евангельских христиан, которые неплохо сосуществовали друг с другом, с представителями буддийской конфессии и староверами. Что касается православных, то отношения с ними были напряженными.

Баптисты, как и российские революционеры разных направлений, имели богатый опыт идеологической борьбы, многие из них прошли через тюрьмы и ссылки. Молодежное движение (Христомол) у них появилось значительно раньше комсомола и ревсомола. В отличие от ряда политических партий, они имели опыт работы, как в легальных (съезды), так и в полулегальных (листовки, конспирация) и нелегальных условиях.

B Туве начала XX в., где местные структуры политических партий не были оформлены, баптисты представляли серьезную общественную силу. Проведение первых съездов, ведение дискуссий, выборы - все эти демократические процедуры уже были им хорошо знакомы. Отчасти этим объясняется их в основном успешная посредническая роль в начальный период военной интервенции в Туве.

Мягкое законодательство и терпимость властей ТНР до конца 1920-х гг. позволяли им играть активную и заметную роль в духовной жизни советских колонистов в Туве, проповедовать среди них и тувинских аратов. Особенно тесно они контактировали со староверами. Общая судьба гонимых, успешная религиозная пропаганда среди староверов, положительный опыт совместного проживания с ними (яркий пример - Успенка) показывают, что староверы и баптисты без труда находили общий язык. Деятельность евангельских христиан-баптистов в Туве была пресечена в связи с ужесточением антирелигиозной борьбы и коллективизацией в СССР, получившими свое распространение и в советской колонии на территории ТНР.

Надеюсь, что с опубликованием настоящей работы история баптизма в ТНР и советской зарубежной колонии в ней станет более ясной и понятной, по крайней мере, в отношении «благоприятного» периода второй половины 1920-х годов. Вместе с тем, вполне осознаю, что работа по созданию полнокровной истории этой конфессии в Туве только начата. Пока еще все сделанное в исследовании этого вопроса выглядит по большей части фрагментарно. Не так давно совершенно неизученной выглядела история старообрядчества в Туве, но после защиты диссертации по теме А. А. Стороженко (Стороженко, 2004) и монографии М. П. Татаринцевой (Татаринцева, 2006) в исследовании этой проблемы произошел прорыв. Теперь необходимы усилия в части изучения протестантизма, в том числе евангельских христиан и баптистов. Время систематизации и обобщающих выводов еще не пришло. Дальнейшее продолжение исследования в этом направлении потребует, прежде всего, поиска и анализа новых исторических источников, последовательного воссоздания цельной картины прошлого.

\section{Благодарности}

Благодарю за квалифицированное и своевременное консультирование Алену Александровну Стороженко, за компьютерную помощь Антона Анатольевича Асонычева. 


\section{СПИСОК ЛИТЕРАТУРЫ}

Бадмаев, А. А., Адыгбай, Ч. О., Бурнаков, В. А., Маншеев, Д. М. (2006). Протестантизм и народы Южной Сибири: история и современность. Новосибирск : Редакционно-издательский центр НГУ. 160 с.

Большая Советская Энциклопедия (1931). М. : 16-я типография треста «Полиграфкнига». T. 23. 837 c.

Вебер, М. (1990) Избранные произведения. М. : Прогресс. 808 с.

История Тувы (2007) / под ред. В. А. Ламина. Новосибирск : Наука. Т. 2. 430 с.

Крыжановский, Р. (2011) Кто такие баптисты? Одесса : ХГЭУ. 142 с.

Сперанская, Е. С., Леоненкова, И. Р. Баптисты [Электронный ресурс] // Православная энциклопедия под редакцией патриарха Московского и всея Руси Кирилла. URL: www/pravenc.ru/ teht/77510.html (дата обращения: 11.12.2018).

Религиоведение (2002) : учебное пособие и учебный словарь-минимум по религиоведению / под ред. И. Н. Яблокова. М. : Гардарика. 536 с.

Стороженко, А. А. (2004) Старообрядчество Тувы во второй половине XIX - первой четверти ХX вв. : автореф. дисс. ... к. ист. н. Кызыл. 23 с.

Татаринцева, М. П. (2006) Старообрядцы в Туве. Новосибирск : Наука. 214 с.

Дата поступления: 12.12.2018 2.

\section{REFERENCES}

Badmayev, A. A., Adygbai, Ch. O., Burnakov, V. A. and Mansheev, D. M. (2006). Protestantizm $i$ narody Iuzhnoi Sibiri: istoriia i sovremennost' [Protestantism and the peoples of southern Siberia: history and modernity]. Novosibirsk, Redaktsionno-izdatel'skii tsentr NGU. 160 p. (In Russ.).

Bol'shaia Sovetskaia Entsiklopediia [Great Soviet Encyclopedia] (1931). Moscow, 16-ia tipografiia tresta «Poligrafkniga». Vol. 23. 837 p. (In Russ.).

Weber, M. (1990) Izbrannye proizvedeniia [Selected works]. Moscow, Progress. 808 p. (In Russ.).

Istoriia Tuvy [The History Of Tuva] (2007) / ed. by V. A. Lamin. Novosibirsk, Nauka. Vol. 2. 430 p. (In Russ.).

Krzyzhanovskii, R. (2011) Kto takie baptisty? [Who are Baptists?]. Odessa, KhGEU. 142 p. (In Russ.).

Speranskaia, E. S. and Leonenkova, I. R. Baptisty [Baptists]. Pravoslavnaia entsiklopediia pod redaktsiei patriarkha Moskovskogo i vseia Rusi Kirilla [online] Available at: www/pravenc.ru/ teht/77510.html (access date: 11.12.2018). (In Russ.).

Religiovedenie [Religious studies] (2002): a textbook and basic dictionary in religious studies / ed. by I. N. Iablokov. Moscow, Gardarika. 536 p. (In Russ.).

Storozhenko, A. A. (2004) Staroobriadchestvo Tuvy vo vtoroi polovine XIX - pervoi chetverti XX vv. [Old Believers of Tuva from the second half of 19th to the first quarter of 20th centuries]: Thesis of Diss.... Candidate of History. Kyzyl. 23 p. (In Russ.).

Tatarintseva, M. P. (2006) Staroobriadtsy v Tuve [Old believers in Tuva]. Novosibirsk, Nauka. 214 p. (In Russ.).

Submission date: 12.12 .2018 . 